\section{Snigur 0., Marchuk Yu., Prazhennik Yu., Bondarenko B.}

\title{
RESEARCH OF THE PROCESS OF SOLID COMBINED FUELS GASIFICATION
}

Об’єктом дослідження є комбіноване 2-компонентне тверде паливо «вугілля-ТПВ» (ТПВ - тверді побутові відходи) у 5 навісках з концентраціями 0-100 (мас. \%) кожного компоненту. Одним з найбільш проблемних місць є удосконалення процесів газифікащї ТПВ, зокрема оптимізація характеристик синтез-газу.

В ході дослідження використовувалася лабораторна термогравітаційна установка, яка являє собою фізичну модель реактору проточного типу з рециркуляцією проміжних продуктів реакцї. До складу цієї установки входять блок установки ТГА (термогравіметричного аналізу), хроматограф, комп'ютер з принтером, система автоматичної оброки даних за допомогою комп'ютерних методів, а саме: термогравіметричного та хроматографічного аналізу.

У ході дослідження показано, що методом комплексного (ТГА+газового) лабораторного аналізу можна оцінювати теплотворну здатність нетрадиційних, зокрема комбінованих, палив. Отримано визначення залежності теплотворної здатності продуктів газифікацї комбінованих палив від їх складу та параметрів

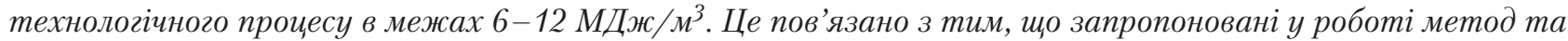
установка має ряд особливостей, зокрема можливість підтримки теплотворної здатності нетрадиційних, зокрема комбінованих палив, на заданому рівні. Досягнення ефекту очікується за рахунок вибору концентрацій компонентів, які відповідають заданому значенню $Q_{\psi}^{p}$. Завдяки цьому забезпечується можливість отримання незмінних значень $Q_{н}^{p}$ при надходженні різних партій ТПВ на виробництво синтез-газу без корекції технологічних параметрів.

Наведена у роботі методика дозволяє проводити експрес-оцінку різних партій ТПВ та визначати оптимальне співвідношення «вугілля-ТПВ». У порівнянні з аналогічними відомими методами, це забезпечує такі переваги: стабільність технологічних параметрів, інтенсифікацію виробництва та здешевлення синтез-газу.

Ключові слова: комбіноване 2-компонентне тверде паливо, тверді побутові відходи, системи газифікації, теплотворна здатність синтез-газу.

Received date: 04.09.2019

Accepted date: 27.09.2019

Published date: 30.12 .2019
Copyright (C) 2019, Snigur O., Marchuk Yu., Prazhennik Yu., Bondarenko B. This is an open access article under the CC BY license (http://creativecommons.org/licenses/by/4.0)

\section{Introduction}

Over the past two decades, interest in the energyefficient use of municipal solid waste has increased significantly [1-3]. Mainly due to reduced availability of fossil fuels, increased energy consumption and negative environmental impact [4]. Studies conducted to determine the morphological and elemental composition of municipal solid waste (MSW) [5-7]. It is proved that solid waste (or individual components) can be used as fuel in the processes of thermochemical conversion.

Research is being carried out in the direction of joint gasification at existing gas generator sets [8-10], that is, joint gasification has become an attractive option for improving gasification processes, in particular for optimizing the characteristics of synthesis gas. But the research results are still not sufficient to create a technology for the production of standardized combined fuels such as coal-solid waste for existing gasification systems. The relevance of this research lies in a detailed study of the influence of the parameters of the process of gasification of combined fuels on the calorific value of the resulting synthesis gas.

Thus, the object of study is a combined 2-component solid fuel «coal-MSW» in 5 samples with concentrations of 0-100 (wt. \%) of each component:

1. Enriched coal of «Bilorichenska» mine (urban-type settlement Bilorichenskyi, Luhansk region, Ukraine), $W^{a}=4.7$, dry weight: $C^{d}=69.28 ; H^{d}=4.63 ; N^{d}=1.52 ; S_{t}^{d}=3.96 ; O_{d}^{d}=$ $=5.21 ; A^{d}=15.4 ; Q_{H}^{p}=26.67 \mathrm{MJ} / \mathrm{kg}$.

2. Model MSW (ground wood pellets). Analytical mass: $C^{a}=48.04 ; H^{a}=7.03 ; S^{a}=3.0 ; O^{a}=25.41 ; A^{a}=11.52 ; W^{a}=5.00 ;$ $Q_{H}^{p}=21.08 \mathrm{MJ} / \mathrm{kg}$.

Sample weight: $M_{\Sigma}=16 \mathrm{~g}$ (constant throughout the study).

Table 1 provides contents of samples and the value of $Q_{H}^{p}$ in experiments No.1-5.

The aim of research is the experimental determination of the dependence of the calorific value of gasification products of combined fuels on their composition and process parameters. 
Combined fuel composition

Table 1

\begin{tabular}{|c|c|c|c|c|c|c|c|c|c|c|}
\hline \multirow{2}{*}{ Sample* } & \multicolumn{2}{|c|}{ Mass, g } & \multicolumn{7}{|c|}{ Working mass, wt. \% } & \multirow{2}{*}{$\square_{H}{ }^{P}, \mathrm{MJ} / \mathrm{kg}$} \\
\hline & Coal & MSW & ᄃ & $\mathrm{H}$ & $\mathrm{N}$ & 5 & 0 & A & W & \\
\hline 1 & 16 & 0 & 66.0 & 4.4 & 1.4 & 3.8 & 5.0 & 14.7 & 4.7 & 26.7 \\
\hline 2 & 12 & 4 & 61.5 & 5.0 & 1.2 & 3.6 & 10.1 & 13.9 & 4.8 & 25.3 \\
\hline 3 & 8 & 8 & 57.0 & 5.5 & 0.9 & 3.4 & 15.2 & 13.1 & 4.9 & 23.9 \\
\hline 4 & 4 & 12 & 52.5 & 6.1 & 0.6 & 3.2 & 20.3 & 12.3 & 4.9 & 22.5 \\
\hline 5 & 0 & 16 & 48.0 & 6.7 & 0.3 & 3.0 & 25.4 & 11.5 & 5.0 & 21.1 \\
\hline
\end{tabular}

Note: ${ }^{*}$ - corresponds to the number of an individual experiment; MSW - municipal solid waste

\section{Methods of research}

The experimental device is developed, created, and tested at the Gas Institute of the National Academy of Sciences of Ukraine (Kyiv, Ukraine).

The laboratory thermogravity unit is a physical model of a flow-type reactor with recirculation of intermediate reaction products (Fig. 1).

The main unit of the installation of thermogravimetric (TGA) analysis $1-2$ is designed as a flow-type reactor with external heating and/or compensation for heat loss, with a mass sensor 7 and thermocouples installed at points $10-12$. Recirculation is provided by elastic tanks 5,6 . The unit is equipped with a chromatograph 16 , a computer 17 with a printer 18 .

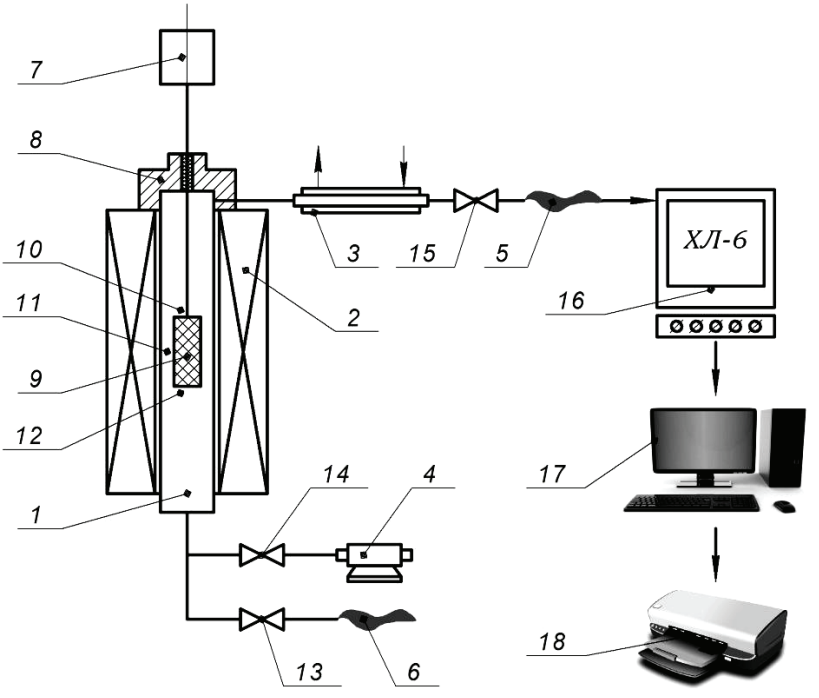

Fig. 1. Scheme of the laboratory unit:

1 - геactor; 2 - oven; 3 - refrigerator; 4 - compressor; 5, 6 - elastic capacity; 7 - mass sensor; 8 - cover; 9 - basket with a hitch; 10-12 - temperature measurement points; $13-15$ - valve; 16 - chromatograph; 17 - computer; 18 - printer

The sample is placed in a cylindrical basket, the surface of which is made of heat-resistant mesh and forms an annular gap with the inner wall of the reactor. When air moves in the reactor, most of it passes through the annular gap, as a result of which most of the air does not have time to oxidize the fuel, but enters directly into the refrigerator. In the first cycle, with open valve 14 and closed 13, air is supplied to the reactor, and the gas flow from the reactor through the refrigerator and valve 15 enters the elastic tank 5. The total amount of air supplied in the first cycle corresponds to the theoretical value of the air flow coefficient $\alpha$ calculated by conditions for complete gasification of the sample to $\mathrm{CO}+\mathrm{H}_{2}$. The air supply in the first cycle starts from the moment the sample temperature reaches $200-300{ }^{\circ} \mathrm{C}$, when the release of volatile, primarily permanent gases, then higher hydrocarbons begins. After air intake, the compressor is turned off, valve 15 is closed, and containers 5 and 6 are interchanged. At the inlet of the reactor close valve 14 open 13 and from the input tank serves through the reactor and the refrigerator in the original tank. The gas flow is regulated by the selection of external pressure at the inlet tank. Each experiment with one hitch (from No. 1 to No. 5) consists of six cycles. At the end of each cycle, gasification products are analyzed on a chromatograph. Analysis results are processed automatically.

The computer-aided data processing system, which is part of the unit, provides enhanced functionality for the experiment and facilitates further systematization of the results.

The power transmission unit is manufactured and centrifugal with high accuracy, due to which the load on the sensor is directed strictly vertically. The signals from thermocouples and strain gauges are fed to the inputs of an analog-to-digital converter, which is connected to the computer by an interface converter, forms data packets and transmits them. To protect the sensor from thermal radiation and the harmful effects of hot gases, horizontal thermal screens of heat-resistant heat-insulating material are installed between it and the reactor. The reactor-sensor system is located under the exhaust system.

Data obtained during the laboratory experiment, presented in analog form. An analog-to-digital interface is required for a data acquisition system. It converts the source data from one or more transmitters into an output signal suitable for digital processing.

The data acquisition system was created on the basis of a computer, an 8-channel module M-7019 and an interface converter I-7561. The ICPCON M7019 module (Taiwan) is the main component because it acts as an analog signal converter, has a 16-bit resolution, a sampling frequency of $8 \mathrm{~Hz}$, and a measurement error of $+/-1 \%$. The ICPCON I-7561 module (Taiwan) acts as a gateway between the M-7019 and the computer. To manage laboratory experience, specialized software based on the LabView complex has been developed.

After the end of the experiment, a sample of the cokeash residue from the basket is burned in a stream of air to a constant mass, which is the ash content in the sample. 
The sensor signal, as well as signals from thermocouples, is synchronously fed to the computer after processing the sensor message modules in the system.

\section{Research results and discussion}

A typical mass-thermogram of a single experiment is shown in Fig. 2.

The following graphs (Fig. 3) show the nature of the change in the composition of the gas phase according to the degrees of its recirculation in the reactor.

The following graph (Fig. 4) shows the change in the calorific value of the generator gas during the experiment, as well as the dependence of the latter on the initial fuel.

As it is known, volatiles are not contained in the fuel as individual substances, but are formed when the fuel is heated (which is why it is not possible to talk about the «contents» of volatiles, but about their «output»). The composition of volatiles includes, in addition to light gases, as well as other more complex gaseous hydrocarbons. The change in mass depending on the composition of the sample occurs in the temperature range from $(200-300){ }^{\circ} \mathrm{C}$ to $\sim 800{ }^{\circ} \mathrm{C}$; it is in it that volatiles exit. The results are shown in Table 2.

The nature of the change $\Delta M$ (Table 2) corresponds to the data on the yield of volatile substances:

- coal of «Bilorichenska» mine -

30.8 (on a dry weight);

- MSW - from 80-90 (paper, textiles, plastics) to 50-65 (leather, rubber, food waste, etc.)
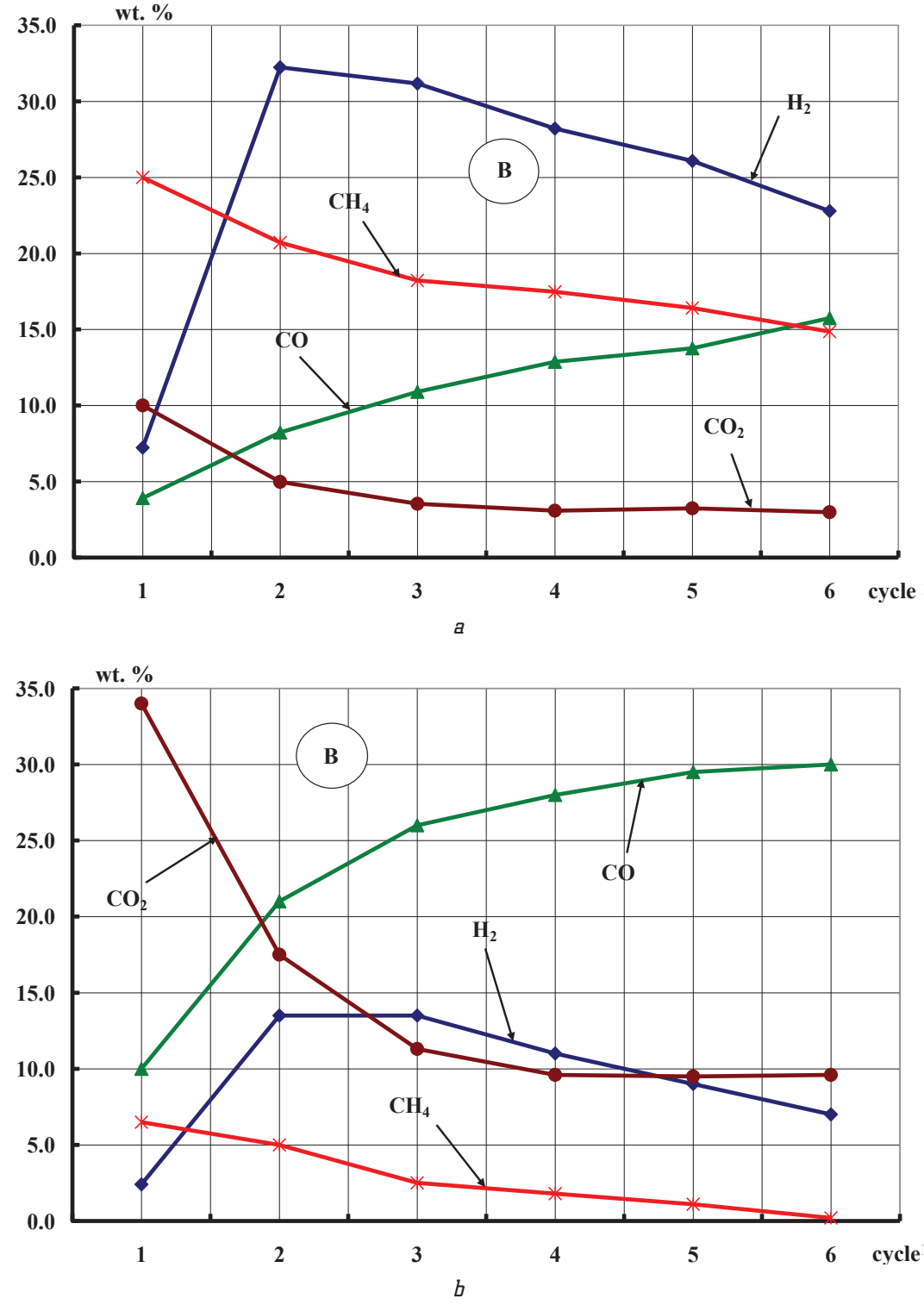

Fig. 3. Examples of changes in the composition of the gas mixture in individual experiments: $a$ - experiment No. 1 (coal); $b$ - experiment No. 5 (MSW)

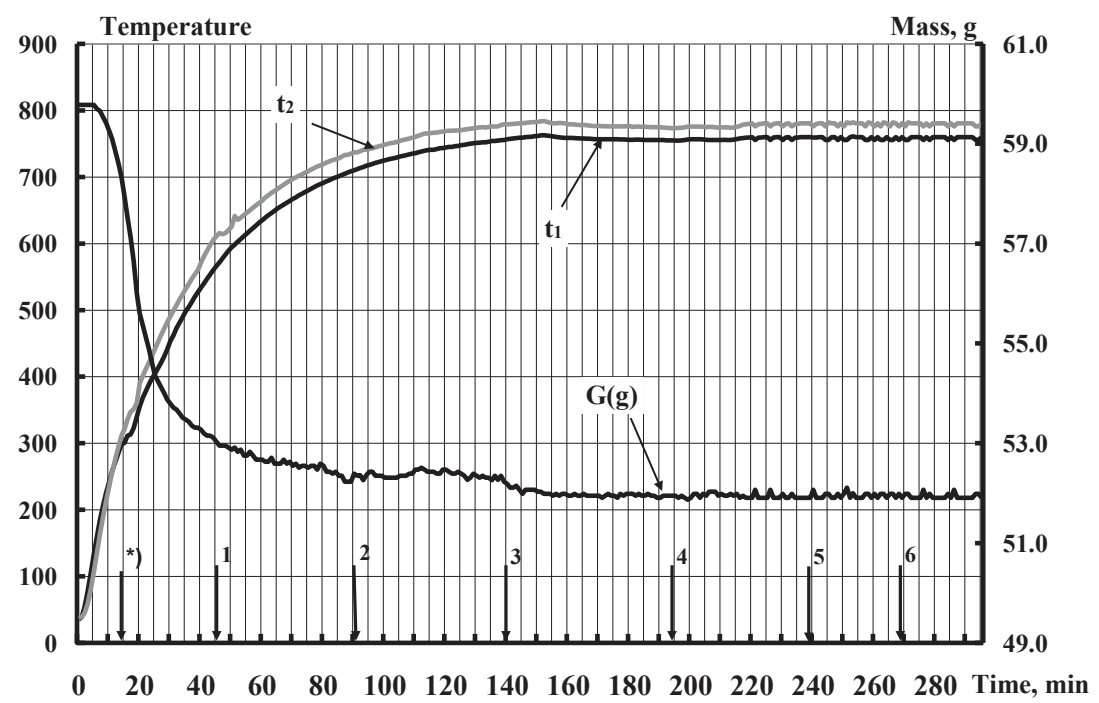

Fig. 2. The nature of the change in the mass of the sample and temperatures in the reactor during a single experiment. Sample: coal - 8 g, solid waste - 8 g. Marks 1-6 - cycle numbers 
$\mathbf{Q}_{\mathrm{H}}^{\mathrm{p}}, \mathbf{M J} / \mathbf{m}^{3}$

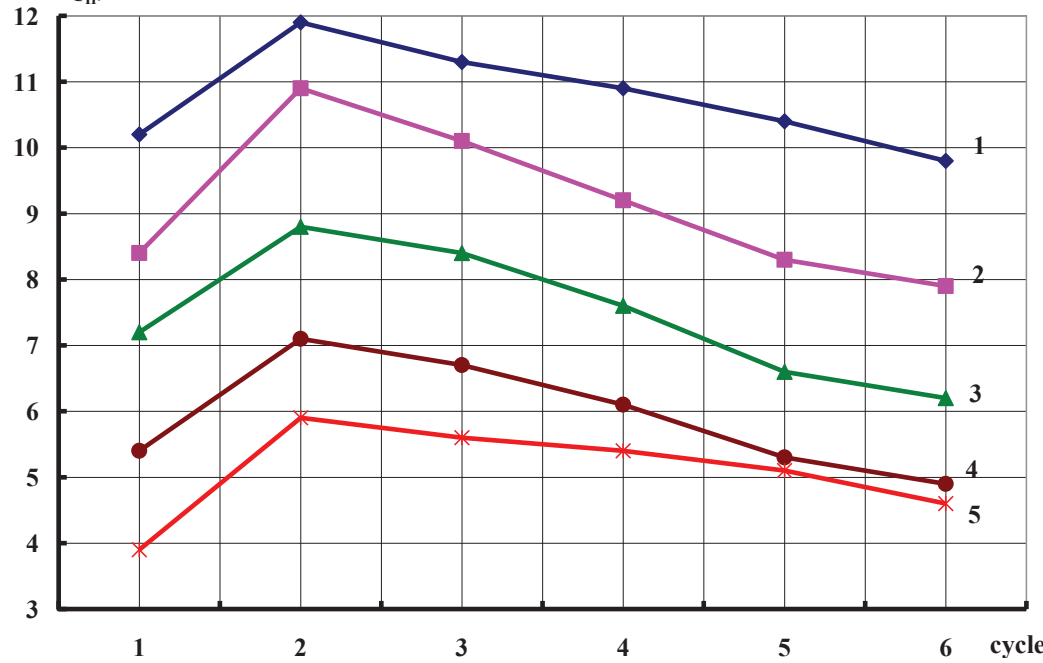

Fig. 4. The dependence of $\emptyset_{H}^{p}$ on the composition of the combined fuel (1-5 - Table 1)

\section{Conclusions}

The research shows that the method of complex (TGA+gas) laboratory analysis can evaluate the calorific value of nontraditional, including combined, fuels.

The technique presented in the work allows for an express assessment of various batches of solid waste and determine the optimal ratio of coal-solid waste.

\section{Acknowledgment}

The study was carried out with the financial support of the NAS of Ukraine Target comprehensive program «Stable development».

\section{References}

1. Klinghoffer, N. B., Castaldi, M. J. (2013). Waste to Energy Conversion Technology. Elsevier, 256. doi: http://doi.org/10.1533/9780857096364

Table 2

The loss of mass of the sample in experiments No. 1-5

\begin{tabular}{|c|c|c|c|c|c|}
\hline No. of experiment & 1 & 2 & 3 & 4 & 5 \\
\hline$\Delta M, g$ & 5.7 & 8.9 & 10.4 & 11.3 & 12.0 \\
\hline
\end{tabular}

The nature of the curves of mass and temperature as a function of time is the same for all the samples of different composition (Fig. 2). Examination of the thermogram shows that the gasification process almost completely ends in the 2nd cycle, which is confirmed by the maximum mass loss $G$ (g).

Graphs in Fig. 3 characterizes the sequence of generation of generator gas, which allows to trace the first two stages of the gasification process in reactors with intense interfacial mass transfer: the complete oxidation of combustible components to $\mathrm{CO}_{2}$ (and, accordingly, $\mathrm{H}_{2} \mathrm{O}$ ). As well as their further oxidation of $\mathrm{CH}_{4}$ and the final carbon to $\mathrm{CO}$ and $\mathrm{H}_{2}-$ as, for example, in reactors with an accompanying stream of reagents. The sum $\left(\mathrm{CO}+\mathrm{H}_{2}\right)=40 \%$ in experiment 1 does not change from the 2 nd to the 6 th cycle, and in experiment 5 it slightly increases from $34 \%$ to $37 \%$. In this case, a decrease in the concentration of $\mathrm{H}_{2}$ with a simultaneous increase in the concentration of $\mathrm{CO}$ is explained by a shift in the reaction of water gas as a result of heating of the reagents at a constant temperature of about $800{ }^{\circ} \mathrm{C}$.

$Q_{H}^{p}$ reaches a maximum for each combination of coalMSW (Fig. 4). In subsequent recirculation cycles, a uniform decrease in this value is observed, possibly with the loss of heavy volatile (resins, etc.) due to their condensation in the refrigerator and further along the path in front of the reactor. The similarity of the curves for all coal-MSW compositions corresponds to the additivity of $Q_{H}^{p}$ values. As a result of this, when developing an autothermal process for the thermochemical disposal of solid waste, it becomes possible, by regulating the coal-solid waste ratio, to achieve a constant value of $Q_{H}^{p}$ upon receipt of various batches of waste of various compositions.
2. Young, G. C. (2010). Municipal solid waste to energy conversion processes: economic, technical, and renewable comparisons. John Wiley \& Sons, 396. doi: http://doi.org/10.1002/9780470608616

3. Rogoff, M. J., Screve, F. (2011). Waste-to-Energy: Technologies and Project Implementation. Elsevier, 184.

4. Bilitewski, B., Härdtle, G., Marek, K. (2013). Waste Management. Springer Science \& Business Median, 699.

5. Shmarin, S. L., Luchko, I. A. (2011). Pomesiachnoe izmenenie morfologicheskogo sostava, kaloriinosti, vlazhnosti i zolnosti tverdykh bytovykh otkhodov. Visnik Nacionalnogo tekhnichnogo universitetu Ukraini «Kiivskii politekhnichnii institut». Seriia: Girnictvo, 21, 136-143.

6. Pliaskina, N. I. (2012). Ocenka energeticheskogo potenciala utilizacii tverdykh bytovykh otkhodov (na primere Novosibirskoi oblasti). Gorenie tverdogo topliva. Available at: http:// www.itp.nsc.ru/conferences/gtt8/files/79Plyaskina.pdf

7. Mikhailenko, V. P., Alekseevec, I. L., Denafas, G., Shmarin, S. L. Luchko, I. A. Osobennosti sostava tverdykh bytovykh otkhodoz v Ukraine. Available at: http://www.myshared.ru/slide/188864/

8. Farzad, S., Mandegari, M. A., Görgens, J. F. (2016). A critical review on biomass gasification, co-gasification, and their environmental assessments. Biofuel Research Journal, 3 (4), 483-495. doi: http://doi.org/10.18331/brj2016.3.4.3

9. Tanigaki, N., Ishida, Y., Osada, M. (2012). A case-study of landfill minimization and material recovery via waste co-gasification in a new waste management scheme. Elsevier Waste Management, 32 (4), 667-675.

10. Higman, C., van der Burgt, M. (2008). Gasification. Gulf Professional Publishing, 456. doi: http://doi.org/10.1016/b978-07506-8528-3.x0001-6

Snigur Oleksandr, Researcher, Department of Gas Thermal Processes and Nanotechnologies, Institute of Gas of National Academy of Sciences of Ukraine, Kyiv, Ukraine, e-mail: umarch@i.com.ua, ORCID: http://orcid.org/0000-0001-7100-850X

Marchuk Yurii, PhD, Senior Researcher, Department of Gas Thermal Processes and Nanotechnologies, Institute of Gas of the National Academy of Sciences of Ukraine, Kyiv, Ukraine, e-mail umarch@i.com.ua, ORCID: http://orcid.org/0000-0001-5226-2174

Prazhennik Yurii, Senior Researcher, Department of Gas Thermal Processes and Nanotechnologies, Institute of Gas of the National Academy of Sciences of Ukraine, Kyiv, Ukraine, e-mail: umarch@i.com.ua, ORCID: http://orcid.org/0000-0002-4264-7959

Bondarenko Borys, Doctor of Technical Sciences, Professor, Academician of NAS of Ukraine, Head of Department, Director of the Institute, Department of Gas Thermal Processes and Nanotechnologies, Institute of Gas of the National Academy of Sciences of Ukraine, Kyiv, Ukraine, e-mail: bbikiev@gmail.com,ORCID: http://orcid.org/ 0000-0002-8211-0419 